\title{
IPTEKS PROSEDUR PENGHAPUSAN BMN OLEH KPKNL MANADO
}

\author{
Andrew Malahasa Karambut ${ }^{1}$, Reinaldi Lasewa ${ }^{2}$, Hendrik Gamaliel ${ }^{3}$ \\ ${ }^{1,2.3}$ Jurusan Akuntansi, Fakultas Ekonomi dan Bisnis, Universitas Sam Ratulangi, Jl. Kampus Bahu, Manado, \\ 95115, Indonesia \\ E-mail : karambutandrew@gmail.com
}

\begin{abstract}
In order manifest procedure deletion State wealth, accountability management Goods State property, destruction State wealth, and deletion State wealth, necessary existence the implementation of an efficient, if efekt and take responsibility answer in Goods State Property. total State assets which are in condition broken will to be problem in BMN management but should reported on report Goods State- owned or Balance sheet. On party the user goods required take responsibility answer in take care of and make use of Goods State- owned with the best that includes age economical, period benefits, shrinkage and supervision should always in report every the period to party always manager goods namely KPKNL Manado. Value The presented in balance is asset still. By because that, necessary there is effective management on Goods State property to produce balance sheet that can reliable with facts that occur in the field. Elimination Goods State Ownership is the last process in management Goods State- owned.
\end{abstract}

Keywords : Procedures, State Property, Deletion

\section{PENDAHULUAN}

Setiap satuan kerja memiliki tugas dan wewenang masing-masing dalam menunjang pelayanannya kepada masyarakat. Kementerian Keuangan adalah kementerian di lingkungan pemerintah Indonesia yang mengurus bidang keuangan negara serta kekayaan negara. Kementerian Keuangan ini dipimpin oleh seorang Menteri Keuangan berkedudukan dibawah dan bertanggung jawab kepada Presiden, yang bertindak sebagai Chief Financial Officer ( $C F O$ ). Seluruh BMN di kementerian atau lembaga dikelola DJKN serta KPKNL bertindak sebagai unit vertikal. Pengelolaan BMN akan optimal jika dilakukan sama-sama antara DJKN pengelola BMN dan satker serta kementerian atau lembaga sebagai pengguna BMN. Menteri Keuangan mempunyai tugas, tanggung jawab serta kewenangan dalam pengololaan aset negara dicantumkan dalam Peraturan Pemerintah Nomor 27 tahun 2014 tentang Pengolahan Barang Milik Negara/Daerah. Penggunaan dana APBN menjadi keharusan dalam menyajikan Barang Milik Negara dalam neraca berupa persediaan dan aset tetap pada laporan keuangan. Dalam Penghapusan BMN ini adalah tahap akhir dari pengelolaan BMN dan selanjutnya akan kembali pada proses awal yaitu pengadaan. Untuk membebaskan pengurusan dalam Barang Milik Negara maka dilakukan suatu tindakan yaitu penghapusan BMN.

Munculnya Keputusan pengahapusan Barang Milik Negara ini dalam prosedur ini penghapusan Barang Milik Negara kadang dianggap rumit dan memakan waktu lebih, sehingga tidak jarang didapati barang yang sudah tidak dapat dioperasikan atau tidak dapat memberikan kontribusi pada setiap kegiatan operasional namun belum melalukan penghapusan Barang Milik Negera tersebut maka akan dapat menimbulkan biaya berlebih serta pemeliharaan berlebih pada Barang Milik Negera tersebut.

\section{TINJAUAN PUSTAKA}

Penghapusan BMN, Dimana suatu tindakan penghapusan BMN dalam daftar BMN dengan menerbitkan keputusan dari pejabat yang memiliki kewenangan dalam membebaskan 
tanggung jawab serta fisik kepada pengguna barang dari penggunan yang ada pada pengawasannya seperti tercantum dalam PMK 83/PMK.06/2016.

Standard Operating Procedure, Untuk memperoleh hasil kerja yang efektif diperlukan prosedur yang kronologis dalam kegiatan operasional. Jones (2004) mengatakan bahwa SOP yaitu mengontrol perilaku anggota pada suatu organisasi adalah bagian dari peraturan tertulis seperti tertuang dalam dalam buku Organizational Theory yang ditulisnya.

\section{METODE DAN TEKNIK PENERAPAN IPTEKS}

\subsection{Metode Penerapan Ipteks}

Metode ipteks yang diterapkan adalah mengimplementasi proses prosedur penghapusan Barang Milik Negara yang berada pada pengelola barang sesuai dengan Peraturan Menteri Keuangan Republik Indonesia Nomor 83/PMK.06/2016 tentang Tata Cara Pelaksanaan Pemusnahan dan Penghapusan Barang Milik Negara.

\subsection{Teknik Penerapan Ipteks}

Teknik ipteks yang diterapkan adalah melakukan pemantauan dan ikut serta membantu penerapan proses prosedur penghapusan BMN sesuai dengan Standard Operating Procedure yang diterapkan di KPKNL Manado.

\section{PEMBAHASAN}

\subsection{Gambaran Objek Penerapan Ipteks}

Kantor Pelayanan Kekayaan Negara dan Lelang Manado merupakan unit pelayanan yang ada dalam lingkungan DJKN suluttenggomalut, kantor ini terletak di lantai IV Gedung Keuangan Negara Jln. Bethesda No. 6-8 Manado dan bagian dari sebuah instansi pemerintah dalam menyelenggarakan pelayanan publik kepada masyarakat di bagian kekayaan negara, penilaian, piutang negara, dan lelang. Dalam penyelenggaraan ini, KPKNL Manado berpedoman pada kebijakan yang ditetapkan oleh kantor pusat DJKN dalam rangka peningkatan kepuasan pengguna jasa. KPKNL Manado saat ini dipimpin oleh Rahmat Mahsan, masing-masing seksi di KPKNL Manado memiliki tugas dan fungsi yang berbeda, salah satunya seksi pengelolaan kekayaan negara yaitu melakukan akuntansi pelaporan serta penyusunan daftar BMN dan kepala KPKNL Manado menerbitkan persetujuan rekapitulasi PNBP yang berasal dari pengelolaan BMN.

\subsection{Pembahasan}

Dalam pengahapusan Barang Milik Negara ini KPKNL Manado selaku instansi vertikal yang membantu dalam penghapusan BMN, karena Barang Milik Negara masuk pada kekayaan negara. Tata cara penghapusan Barang Milik Negara menjadi faktor utama mengapa hal ini terjadi karena ketidaktahuan petugas BMN mengenai hal itu. Faktor lain juga dapat meyebabkan pemusnahan atau penghapusan Barang Milik Negara dikarenakan penghapusan BMN ini dianggap rumit dan juga lama. Selain itu apabila suatu BMN ditemukan dan diperiksa oleh auditor atau penegak hukum karena dasar penghapusannya tidak cukup kuat maka hal tersebut diakibatkan adanya keengganan untuk melakukan inisiasi penghapusan dan juga risiko kerugian negara. Pengolahan Barang Milik Negara ini telah diserahkan dibawahnya DJKN yaitu KPKNL Manado yang ditunjuk sebagai pengelola barang dimiliki negara sebagai kekayaan negara. Pada pihak pengguna barang diharuskan bertanggung jawab dalam merawat serta memanfaatkan BMN dengan sebaik-baiknya yang meliputi umur ekonomis, masa manfaat, penyusutan serta pengawasan yang harus selalu dilaporkan setiap periodenya kepada pihak selaku pengelola barang yaitu KPKNL Manado. 


\section{Prosedur penghapusan Barang Milik Negara}

Prosedur penghapusan BMN di KPKNL Manado selaku pengelola barang tercantum di PMK No. 83/PMK.06/2016 yaitu mengenai Tata Cara Pelaksanaan Pemusnahan dan Penghapusan Barang Milik Negara.

\begin{tabular}{|c|c|c|c|c|c|c|c|c|c|c|c|c|}
\hline \multirow{2}{*}{ No } & \multirow{2}{*}{ Kegiatan } & \multicolumn{7}{|c|}{ Pelaksana } & \multicolumn{3}{|c|}{ Mfutu Bakau } & \multirow{2}{*}{ KEI } \\
\hline & & $\begin{array}{c}\text { Tim } \\
\text { HER }\end{array}$ & $\begin{array}{l}\text { Pestata } \\
\text { BMIN }\end{array}$ & KTU & $\begin{array}{c}\text { Kepala } \\
\text { Balai }\end{array}$ & $\begin{array}{c}\text { Biro } \\
\text { Vimumum }\end{array}$ & Selkjen & KPKNL & Kelengkapan & Waktu & Output & \\
\hline 1 & $\begin{array}{l}\text { Mengiaventaris baraeg ye akan } \\
\text { dihapus }\end{array}$ & $\square$ & & & & & & & $\begin{array}{l}\text {-Foto } \\
\text { Refereasi } \\
\text { peanimjung }\end{array}$ & 1 Bulan & 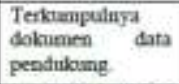 & \\
\hline 2 & 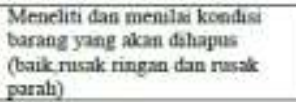 & & & & & & & & $\begin{array}{l}\text { Daffar barragg } \\
\text { yane akan } \\
\text { dillagus }\end{array}$ & 1 Butas & $\begin{array}{l}\text { Laporian tim ber } \\
\text { imventaris trati }\end{array}$ & \\
\hline 3 & $\begin{array}{l}\text { Menbuas laporan hasil keyja } \\
\text { peselitian Kotatisi BMN }\end{array}$ & ] & & & & & & & $\begin{array}{l}\text { Laporan tim } \\
\text { her invertaris } \\
\text { bun }\end{array}$ & I hat & $\begin{array}{l}\text { Saran } \\
\text { penglapusin bman }\end{array}$ & \\
\hline 4 & $\begin{array}{l}\text { Mengequput aplicasi perubahial } \\
\text { kondisi dalam Simak BMN }\end{array}$ & & & & & & & & $\begin{array}{l}\text { Aplikasi simak } \\
\text { BMN }\end{array}$ & $1 \mathrm{han}$ & $\begin{array}{l}\text { Laporas } \\
\text { peruhahan } \\
\text { kondasi barang }\end{array}$ & \\
\hline 5 & $\begin{array}{l}\text { Memienikss dan meemberi paraf } \\
\text { pada hasit liporan kondiat } \\
\text { BMN. }\end{array}$ & & & & & & & & $\begin{array}{l}\text { Laporan } \\
\text { perubahan } \\
\text { koodist tarang }\end{array}$ & then & 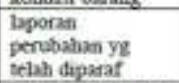 & \\
\hline 6 & $\begin{array}{l}\text { Meruyehajui dan } \\
\text { memandatangani hasil laporan } \\
\text { koondisi BMEN }\end{array}$ & & ridus & क्सेत्र & & & & & $\begin{array}{l}\begin{array}{l}\text { laporat } \\
\text { perubathan yg } \\
\text { telaht diparaf }\end{array} \\
\end{array}$ & thani & 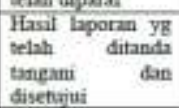 & \\
\hline 7 & $\begin{array}{l}\text { Melakikikan pengajuan } \\
\text { penghapusas BMN ke Biro } \\
\text { Unumu }\end{array}$ & & & & & $\mathrm{r}_{\mathrm{a}}$ & & & $\begin{array}{l}\text { Hascil laporan } \\
\text { Yg disenajui }\end{array}$ & 3 Butan & $\begin{array}{l}\text { Hasil lagoran } \\
\text { diteliti }\end{array}$ & \\
\hline 8 & $\begin{array}{l}\text { Menerika peneagisan } \\
\text { penghispusan BMMN }\end{array}$ & & & & & & & & $\begin{array}{l}\text { Hasil laporan } \\
\text { deteliti }\end{array}$ & 3 bulan & $\begin{array}{l}\text { Hasil laporan yg } \\
\text { disetujua bito } \\
\text { umum }\end{array}$ & \\
\hline
\end{tabular}

\begin{tabular}{|c|c|c|c|c|c|c|c|c|c|c|c|c|}
\hline \multirow{2}{*}{ No } & \multirow{2}{*}{ Keggiatan } & \multicolumn{7}{|c|}{ Pelaksana } & \multicolumn{3}{|c|}{ Mutu Baku } & \multirow[b]{2}{*}{ KEI } \\
\hline & & $\begin{array}{l}\text { Tim } \\
\text { HER }\end{array}$ & $\begin{array}{l}\text { Penata } \\
\text { BMIN }\end{array}$ & KTU & $\begin{array}{c}\text { Kepala } \\
\text { Balai }\end{array}$ & $\begin{array}{l}\text { Biro } \\
\text { Cmum }\end{array}$ & Sekjen & KPKNL & Kelengkapan & Waktu & Output & \\
\hline 9. & $\begin{array}{l}\text { Menginim hasil persetujuan } \\
\text { penghapusa BMN }\end{array}$ & & & & & & & & $\begin{array}{l}\text { Hasil laporan yg } \\
\text { disethiju bero } \\
\text { ummin }\end{array}$ & 2 balan & $\begin{array}{l}\text { Laporan ditelifi } \\
\text { oleh sekjen }\end{array}$ & \\
\hline 10 & $\begin{array}{l}\text { Memerenksa hasil persethiuan } \\
\text { penglapusan BMN }\end{array}$ & & & & Tiads & & & & $\begin{array}{l}\text { Laporan ditelifi } \\
\text { oleh selgen }\end{array}$ & 2 bulan & $\begin{array}{l}\text { Menelaah taporan } \\
\text { pengajuan }\end{array}$ & \\
\hline 11 & $\begin{array}{l}\text { Menerima Persetyyan inin } \\
\text { penghapusa BMN }\end{array}$ & & & & & & & & $\begin{array}{l}\text { Laporan } \\
\text { pengajuan BMN }\end{array}$ & 2 bulan & $\begin{array}{l}\text { Persetyjuan } \\
\text { Pegnghapusan } \\
\text { BMN }\end{array}$ & \\
\hline 12. & $\begin{array}{l}\text { Mengajukan Permohonen lelang } \\
\text { BMN }\end{array}$ & & 7 & & & & & & $\begin{array}{l}\text { Persetujuan } \\
\text { Pegnghapusan } \\
\text { BMN }\end{array}$ & 2 bulan & $\begin{array}{l}\text { Menetbifkan } \\
\text { jadval }\end{array}$ & \\
\hline 13. & Menerótifan jatual lelang BMN & & & & & & & & Surat Persetuyjan & 1 Bulan & Jadval lefang & \\
\hline 14 & Mengadakan lelang BMN & & & & & & & & $\begin{array}{l}\text { Hasil laporan yg } \\
\text { disetujui KPKNL }\end{array}$ & $\begin{array}{c}1 \\
\text { minggu }\end{array}$ & $\begin{array}{l}\text { Pengmminn } \\
\text { lelang barnng }\end{array}$ & \\
\hline 15 & Mengehuarkan Risalah BMN & & & & & & & $T$ & $\begin{array}{l}\text { Pengminuan } \\
\text { lelang barang }\end{array}$ & 1 bari & & \\
\hline 16 & $\begin{array}{l}\text { Menivuat surat penghapusan } \\
\text { BMN dari datara dan } \\
\text { mengarsipkan }\end{array}$ & & & & & & & & Ordner file lentari & $\begin{array}{l}10 \\
\text { menit }\end{array}$ & $\begin{array}{l}\text { Betikas } \\
\text { penghaquasan } \\
\text { telah diassipkna }\end{array}$ & \\
\hline & & & Tot & & & & & & 1 Th5 & $\tan 11$ & inggu 5 hari $10 \mathrm{M}$ & \\
\hline
\end{tabular}

Oleh karena itu pemusnahan ini juga termasuk dalam lingkup PMK 04/PMK.06/2015 mengenai Pendelegasian Kewenangan dan Tanggung Jawab Tertentu dari Pengelola Barang 
Kepada Pengguna Barang yang dapat didelegasikan kewenangannya kepengguna barang, pengajuannya perlu memperhatikan ketentuan tersebut dan pelaksanaan kegiatan pemusnahan harus dibuat berita acara pemusnahan sebagai dasar untuk pengajuan permohonan penghapusan BMN ke pengguna barang.

\section{KESIMPULAN DAN SARAN}

\subsection{Kesimpulan}

Pada prosedur ini di KPKNL Manado dapat dengan mudah mengurus pengahapusan Barang Milik Negara pada setiap satker yang ingin mengajukan penghapusan Barang Milik Negara. KPKNL Manado dan setiap satker dapat memperhatikan hal-hal diatas dalam mewujudkan pengelolaan BMN yang transparan dan akuntabel, serta untuk memperoleh informasi yang valid dan up to date terhadap pengelolaan Barang Milik Negara.

\subsection{Saran}

Dalam efektifitas penghapusan BMN oleh KPKNL Manado semestinya harus mengukur target utilisasi BMN dalam hal penetapan status penggunaan BMN agar penghapusan BMN bisa efektif, serta mengajukan usulan penetapan status penggunaan terhadap BMN yang belum ditetapkan statusnya. Dengan penggunaan ini penetapan status tersebut, sehingga pengoptimalisasi BMN pun bisa dapat tercapai.

\section{DAFTAR PUSTAKA}

Atmoko, Tjipto. 2012. Standar Operasional Prosedur (SOP) dan Akuntabilitas Kinerja Instansi Pemerintah. Skripsi Unpad. Jakarta.

Demak, Kiay, Namira, Indah, Hendrik Manossoh, Afandi, Dhullo. 2018. Analisis Sitem dan Prosedur Penghapusan Barang Milik Negara Pada Kantor Wilayah Kementrian Agama Provinsi Sulawesi Utara. Jurnal Riset Akuntansi Going Concern, 13(2), 1-8. Universitas Samratulangi. Manado.

Jones, Gareth R. 2004. Organizational Theory. Edisi ke-3. New Jersey. USA.

Kemenkeu Learning Center, Tata Cara Penghapusan BMN karena Proses Pemusnahan BMN [online]

https://klc.kemenkeu.go.id/tata-cara-penghapusan-bmn-karena-proses-pemusnahan-bmn/.

Kemenkeu. Menkeu Tetapkan Aturan Penghapusan BMN [online]

https://www.kemenkeu.go.id/publikasi/berita/menkeu-tetapkan-aturan-penghapusan-bmn/.

Martina, Wawan, Putu, Herwanti, Titiek, Hemanto. 2018. Implementasi Penghapusan Barang Milik Daerah Rusak Berat Pada Pemerintah Kota Mataram. Jurnal Economia, 14(1), 5-14. Universitas Negeri Yogyakarta. Yogyakarta.

Mustika, Rasyadah. 2012. Evaluasi Penatausahaan Aset Tetap Kota Padang. Tesis. Universitas Gajha Mada. Yogyakarta.

Nordiawan, Dedi. 2016. Akuntansi Sektor Publik. Edisi Pertama. Salemba Empat. Jakarta

Peraturan Pemerintah Nomor 27 tahun 2014 mengenai Pengolahan Barang Milik Negara/Daerah.

PMK No. 83/PMK.06/2016 mengenai Tata Cara Pelaksanaan Pemusnahan dan Penghapusan Barang Milik Negara.

PMK No. 04/PMK.06/2015 mengenai Pendelegasian Kewenangan dan Tanggung Jawab Tertentu dari Pengelola Barang Kepada Pengguna Barang.

Undang-Undang Nomor 1 Tahun 2004 tentang Perbendaharaan Negara. 